\title{
DETERMINATION THE BINDING ABILITY OF N-ACETYL CYSTEINE AND ITS DERIVATIVES WITH SARS-COV-2 MAIN PROTEASE USING MOLECULAR DOCKING AND MOLECULAR DYNAMICS STUDIES
}

\author{
A. H. SHNTAIF ${ }^{凶}$, N. A. ALRAZZAK, A. BADER, A. M. ALMARZOQI \\ University of Babylon, College of Science for Women, Iraq; \\ e-mail: ahmed1979sh@gmail.com
}

Received: 25 May 2021; Accepted: 22 September 2021

$N$-acetyl cysteine (NAC) drug has been used as an antioxidant and anti-inflammatory agent in clinical practice and more recently in the treatment of COVID-19 patients. Using docking analysis and molecular dynamics studies we compare the interaction between of $N$-acetyl cysteine and its derivatives with SARS-COV-2 main protease $\left(\mathrm{M}^{\text {pro }}\right)$ which is essential for processing the proteins translated from the viral RNA. The results obtained from this study showed that NAC benzyl ester (NACBn), NAC ethyl ester (NACEt) and NAC amide (NACA) could bind with SARS-COV-2 protease better than NAC drug.

Keywords: $N$-acetyl cysteine, $N$-acetyl cysteine derivatives, main protease, SARS-COV-2, molecular docking, COVID-19.

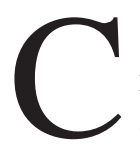

oronaviruses are a diverse category of viruses that infect both humans and some species of animals. These viruses are capable of causing human respiratory infections that are moderate to severe. Furthermore, the recent medical investigations showed that modern coronavirus disease (COVID-19) is triggered by the virus (SARS-CoV-2) causing a multisystem organ dysfunction correlated with severe morbidity and mortality in human [1, 2]. Two extremely pathogenic zoonotic coronaviruses, Acute Respiratory Infection Coronavirus Syndrome (SARS-CoV) and Middle East Respiratory Coronavirus Syndrome (MERS$\mathrm{CoV}$ ), emerged in humans in 2002 and 2012 respectively, resulted in deadly respiratory diseases [10]. In Wuhan Area, China, a new coronavirus identified as SARS-CoV-2 emerged at the end of 2019, triggering an outbreak of unusual viral pneumonia. This novel coronavirus outbreak, COVID-19, has spread widely around the world as a highly communicable disease [3, 4]. Coronavirus disease 2019 (COVID-19) caused by severe acute respiratory syndrome coronavirus 2 (SARS-CoV-2) is an ongoing global health emergency. The 2019-nCoV causes an ongoing outbreak of lower respiratory tract disease called novel coronavirus pneumonia (NCP) by the Chinese government initially. The World Health Organization finally recommended describing the disease as COVID-19. In the meantime, the International Commission on Virus Taxonomy renamed the 2019-nCoV to SARSCoV-2. At the end of January 2020, WHO announced COVID-19 as an international health crisis. On 24 February 2020 over than 80.000 cases were reported which included more than 2,700 deaths that affected at least 37 countries around award. Viruses such as SARS-CoV, SARS-CoV PC4-227, and SARSr-CoVbtKY72 were included in the SARS-CoV genus. The newer part of this viral genus is SARS-CoV-2. SARS in the description of SARS-CoV-2, is an expansion of the taxonomy of viruses of SARS genus, rather than the name of SARS disease. In this species SARS is mainly related to its taxonomic association with this species establishing virus, SARS-CoV. In other words SARS can be referred to as a virus in this genus irrespective of whether or not SARS-like diseases are caused [5]. In addition to seasonal influenza, reported pathogens of pneumonia include adenovirus, coronavirus 229E/NL63/OC43, human

(C) 2021 Shntaif A.H. et al. This is an open-access article distributed under the terms of the Creative Commons Attribution License, which permits unrestricted use, distribution, and reproduction in any medium, provided the original author and source are credited. 
bocavirus, human metapneumovirus, parainfluenza virus $1 / 2 / 3$, rhinovirus and respiratory syncytial virus A/B 2 [6,7]. Moreover, these viruses can cause co-infection in the setting of community-acquired bacterial pneumonia [8]. Awareness of the function of these viruses in pneumonic disease has achieved considerable progress using molecular methods $[9,10]$. A positive sensory, one-strain RNA virus of the genus Betacoronavirus 2 has been found to be a SARS COV-2 [11, 12]. Phylogenetic research found that SARS-CoV-2 was closely linked to two SARS-like bat viruses, namely, bat-SL-CovZC45 (GenBank accession no. MG772933.1) and bat-SLCovZXC21 (GenBank accession no. MG772934.1), but more far away from SARS-CoV ( 79 percent similarity), and Middle East respiratory syndrome (MERS-CoV) [12]. In the 2019 Wuhan Outbreak, Chen et. al. used a next-generation RNA-based metagenomic sequencing technique to diagnose human coronaviruses from two cases of pneumonia. Its whole genome length was 29881 bp [13]. Phylogènetic research reveals that SARS-CoV-2 has a similar characteristic with the bat coronavirus BtCoV/4991 bat coronavirus (Gen Bank KP876546, 370 bp rdRp) and $87.9 \%$ nucleotide similarity to bat coronavirus strain Bat-SL-CoVZC4-5 and bat-SLCosV-45, as well as RNRp (RdRp) partial RNAdependent RNA (RdRp) bat coronavirus strain. An evolutionary research based on the genes ORF1a/1b, $\mathrm{S}$ and $\mathrm{N}$ indicates that SARS-CoV-2 is more likely to be a new corona virus [14]. Based on the results of some genomic research, SARS-CoV-2 infections could be linked to bats slaughters and droppings which can be found in Wuhan seafood market [15]. Many drugs used for the treatment of SARS-Cov-2 are work by the inhibition of protease (Mpro) replication [16, 17]. N-acetyl cysteine (NAC) which have been used as an antioxidant $[18,19]$ due to its ability to facilitates the synthesis of glutathione, has been used to decrease the severity and frequency of wheezing, coughing and respiratory attacks [20-22], it also used to treat acetaminophen overdose [23, 24]. Furthermore, NAC acts as ROS (reactive oxygen species) scavenger [25], therefore it can decreases the inflammation [26].

Also, NAC showed inhibition activity against main protease in viruses, therefore, NAC may improve weakened cellular immunity and avoid the production of certain respiratory viruses, such as HIV and RSV, and has the potential to inhibit SARS-Cov-22 $\left(\mathrm{M}^{\text {pro }}\right)$ [27-29]. The aim of this research was studying the binding of some NAC derivatives with $\mathrm{M}^{\text {pro }}$ of SARS-CoV-2 complex using docking analysis.

\section{Material and Methods}

Molecular docking studies. In this investigation, Autodock tools docking software was used to understand the interaction of NAC, NACBn, NACEt and NACA with $\mathrm{M}^{\text {pro }}$ active site. The crystal structures of the protein 6LU7 of COVID-SARS-2 used in this study was obtained from Databank (https://www.rcsb.org/) as PDB format. The selected drug molecules structures (NAC, NACBn, NACEt and NACA which used as ligands) were obtained from drug bank database as PDB formats, To determine the active site of (6LU7) the position of the native ligand on the binding site (Thr26, Tyr54, Phe140, Asn142, Gly143, Ser144, Cys145, His163, His164, Glu166, and His172) was used.

\section{Results and Discussion}

Because of SARS-COV-2 main protease $\left(\mathrm{M}^{\text {pro }}\right)$ play important rule in replication the major part of research focus on targeting it's with some drugs. It will be useful to use computational biology and chemistry information to predict the binding abilities of 6LU7-the main protease $\left(\mathrm{M}^{\mathrm{pro}}\right)$ of the SARS$\mathrm{CoV}-2$ with drug molecules in order to study the possible interaction with its. The properties of ligands are shown in Table 1. According to the five rules of Lipinski. The values of ligand binding energies

Ta b le 1. Properties of drug molecules/ligands

\begin{tabular}{|l|c|c|c|c|}
\hline & $\mathrm{NAC}$ & $\mathrm{NACBn}$ & $\mathrm{NACEt}$ & $\mathrm{NACA}$ \\
\hline Molecular formula & $\mathrm{C}_{5} \mathrm{H}_{9} \mathrm{NO}_{3} \mathrm{~S}$ & $\mathrm{C}_{7} \mathrm{H}_{13} \mathrm{NO}_{3} \mathrm{~S}$ & $\mathrm{C}_{12} \mathrm{H}_{15} \mathrm{NO}_{3} \mathrm{~S}$ & $\mathrm{C}_{5} \mathrm{H}_{10} \mathrm{~N}_{2} \mathrm{O}_{2} \mathrm{~S}$ \\
\hline Molecular mass $\left(\mathrm{g} \cdot \mathrm{mol}^{-1}\right.$ ) & 163.19 & 191.25 & 253.32 & 162.21 \\
\hline H-bond acceptor count & 3 & 3 & 3 & 2 \\
\hline H-bond donor count & 2 & 1 & 1 & 2 \\
\hline Rotatable bond count & 4 & 6 & 7 & 4 \\
\hline
\end{tabular}


Ta b le 2. Molecular docking results of ligands interaction with main protease of SARS COV-2

\begin{tabular}{|l|c|c|}
\hline \multicolumn{1}{|c|}{ Ligand } & $\begin{array}{c}\text { Binding energy } \\
(\mathrm{kcal} / \mathrm{mol})\end{array}$ & $\begin{array}{c}\text { Inhb-constant } \\
(\mathrm{uM})\end{array}$ \\
\hline NAC & -4.38 & 617.58 \\
\hline NACEt & -4.81 & 296.91 \\
\hline NACBn & -6.15 & 31.28 \\
\hline NACA & -4.98 & 226.2 \\
\hline
\end{tabular}

Table 2 and Auto docking results of ligands with main protease active sites, Fig. 1 shows that NACBn was bound to the GLU166 active site of the main protease, indicating that NACBn has a high ability to inhibit viral RNA replication.

System and ligand stability inside the $M^{\text {pro }}$ active site. As shown in Fig. 2, Calculations of the backbone atom RMSD for the ligand-Mpro complex were used to determine the stability of each simulated model. For all derivatives with $\mathrm{M}^{\text {pro }}$, the RMSD increases to $25 \mathrm{~ns}$ and stabilizes at $2.5 \AA$ after $15 \mathrm{~ns}$. This indicates that inside the pocket, ligands are stabilized and their orientation does not change in the $\mathrm{M}^{\text {pro }}$ active site. Similarly, around $2.5 \AA$ protein backbone atoms for NAC showed stability. NACBn, however, showed increase in the RMSD value and maintained at $3.5 \AA$, which is directly similar to the analysis of the charge. For each residue, the RMSF captures the fluctuations from its average position to determine the flexibility of the $\mathrm{M}^{\text {pro }}$ regions. The parameter RMSF indicates the mobility of the residues. The higher value of RMSF indicates a loosely bonded structure with twists, curves and coils, while the lower value of RMSF indicates a stable secondary structure including alpha-helix and betasheets. We conclude that NACBn does not cause any flexibility as seen from the RMSF outcome and that it is a good complex as opposed to NACBn (Fig. 3). The hydrogen bonding patterns in both ligand complexes were the same (Fig. 4). Until the last simulation, the NACBn had only two hydrogen bonds. Both ligands are stable and form hydrogen bonds with the protein, based on the hydrogen bond findings. from radius of gyration (Rg) During $50 \mathrm{~ns}$ of the process dynamics simulation, the $\mathrm{Rg}$ value of the protein in the complex with NACBn was average about $2.32 \mathrm{~nm}$, which presented that the protein retained a stable structure during MDs (Fig. 5). Fig. 6 shows the change of SASA of native and ligands with time.

Table 3. Information of binding interactions of the potential four ligands docked into active site of the COVID-19 $M^{\text {pro }}$

\begin{tabular}{|l|l|l|}
\hline \multirow{2}{*}{ Ligand } & \multicolumn{1}{|c|}{ Interactions of main protease with ligand atoms } \\
\cline { 2 - 3 } & \multicolumn{1}{|c|}{ Residue } & \multicolumn{1}{|c|}{ Type of interactions } \\
\hline NAC & $\begin{array}{l}\text { HIS163 }(1.89 \mathrm{~A}), \text { SER144 }\left(2.64,3.37 \mathrm{~A}^{0}\right), \\
\text { CYS145 }\left(2.05 \mathrm{~A}^{0}\right) \text { and ASN142 }(2.98)\end{array}$ & H-bond \\
\hline NACEt & $\begin{array}{l}\text { CYS145 }\left(2.06,2.79 \mathrm{~A}^{0}\right), \text { SER144 }(3.49 \mathrm{A0}), \text { ARS142 }\left(3.12 \mathrm{~A}^{0}\right), \\
\text { GLY143 }\left(2.03 \mathrm{~A}^{0}\right), \text { HIS 163 }\left(1.78 \mathrm{~A}^{0}\right) \text { and LES 27 }\left(4.15 \mathrm{~A}^{0}\right)\end{array}$ & $\begin{array}{l}\text { H-Bond, van der } \\
\text { Waals and Pi-Alkyl }\end{array}$ \\
\hline NACBn & $\begin{array}{l}\text { GLN192 }\left(2.12 \mathrm{~A}^{0}\right), \text { THR190 }\left(2.63 \mathrm{~A}^{0}\right), \text { GLU166 }\left(3.28,2.19 \mathrm{~A}^{0}\right), \\
\text { MET165 }\left(3.23,5.45 \mathrm{~A}^{0}\right), \text { MET49 }\left(5.10 \mathrm{~A}^{0}\right) \text { and HIS41 }\left(4.48 \mathrm{~A}^{0}\right)\end{array}$ & $\begin{array}{l}\text { H-Bond, van der Waals, } \\
\text { Pi-Alkyl, Pi-Sulfur } \\
\text { and Pi-Pi T-shaped }\end{array}$ \\
\hline NACA & CYS145 $\left(2.01 \mathrm{~A}^{0}\right)$, SER 144 $\left(2.30,3.43 \mathrm{~A}^{0}\right)$ and HIS163 $\left(1.91 \mathrm{~A}^{0}\right)$ & H-bond \\
\hline
\end{tabular}

Ta b le 4. Some of ADME parameters for the ligands

\begin{tabular}{|l|c|c|c|c|c|c|}
\hline Compound & TPSA $\AA^{2}$ & $\begin{array}{c}\text { Lipophilisty } \\
\text { Log } \mathrm{P}_{\mathrm{o} / \mathrm{w}}\end{array}$ & $\begin{array}{c}\text { Solubility } \\
\text { Log } \mathrm{S}\end{array}$ & $\%$ ABS & Lipinski & $\begin{array}{c}\text { GI } \\
\text { absorption }\end{array}$ \\
\hline NAC & 105.20 & -0.05 & -0.61 & 72.70 & Yes $(0$ violation) & YES \\
\hline NACEt & 94.20 & 0.79 & -1.72 & 76.50 & Yes $(0$ violation) & YES \\
\hline NACBn & 94.20 & 1.77 & -3.85 & 76.50 & Yes $(0$ violation) & YES \\
\hline NACA & 110.99 & -0.39 & -0.82 & 70.70 & Yes $(0$ violation) & YES \\
\hline
\end{tabular}




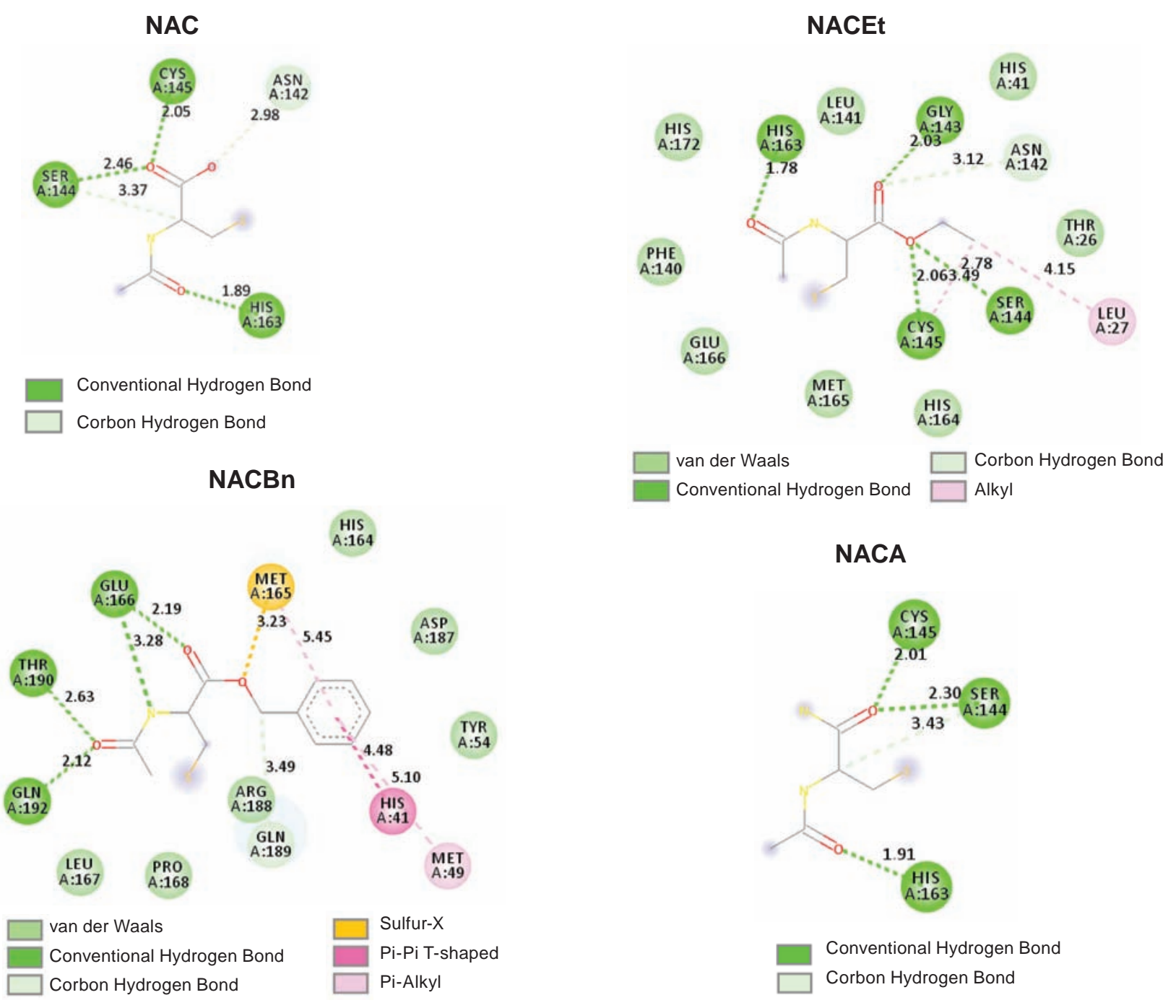

Fig. 1. Two dimensional (2D) binding modes of the four compounds present at the COVID-19 $M^{\text {pro }}$ protease binding site represented by stick structure (1) NAC, (2) NACEt, (3) NACBn, and (4) NACA

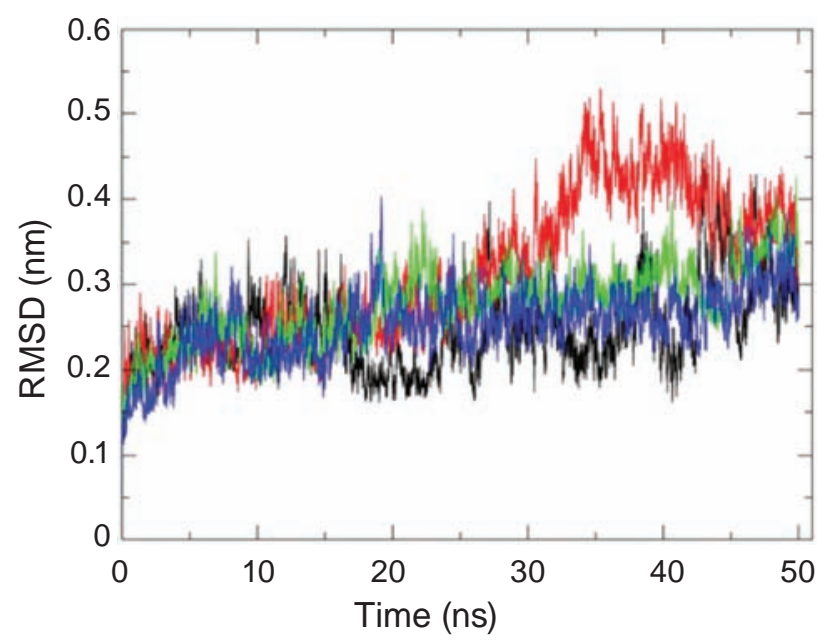

Fig. 2. For the entire $50 \mathrm{~ns}$ MD simulation, the root mean square deviation (RMSD) plots for the NAC, NACEt, NACBn, and NACA compounds interacting with the Mro protease. The black line represent NAC, red line represent NACEt, green line represent NACBn and blew line represent NACA 


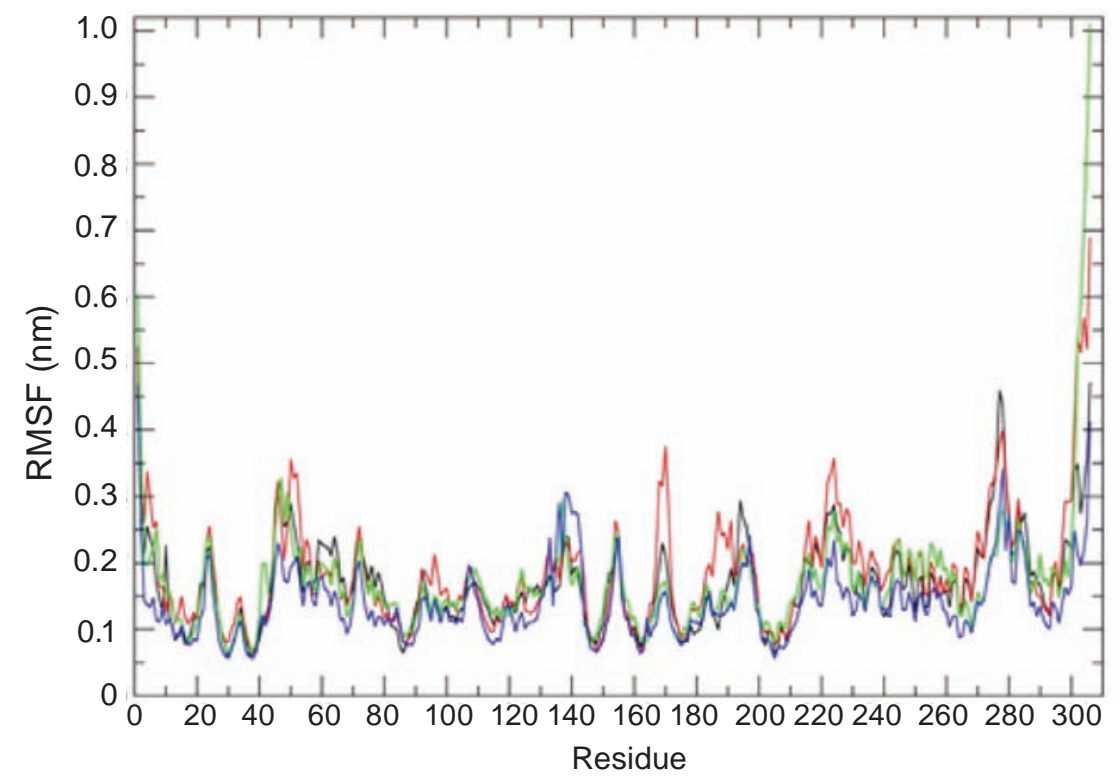

Fig. 3. The root mean square fluctuation (RMSF) for c- $\alpha$ atoms of $M^{\text {pro }}$ and its complexes of last 50 ns trajectory. The black line represent NAC, red line represent NACEt, green line represent NACBn and blew line represent NACA
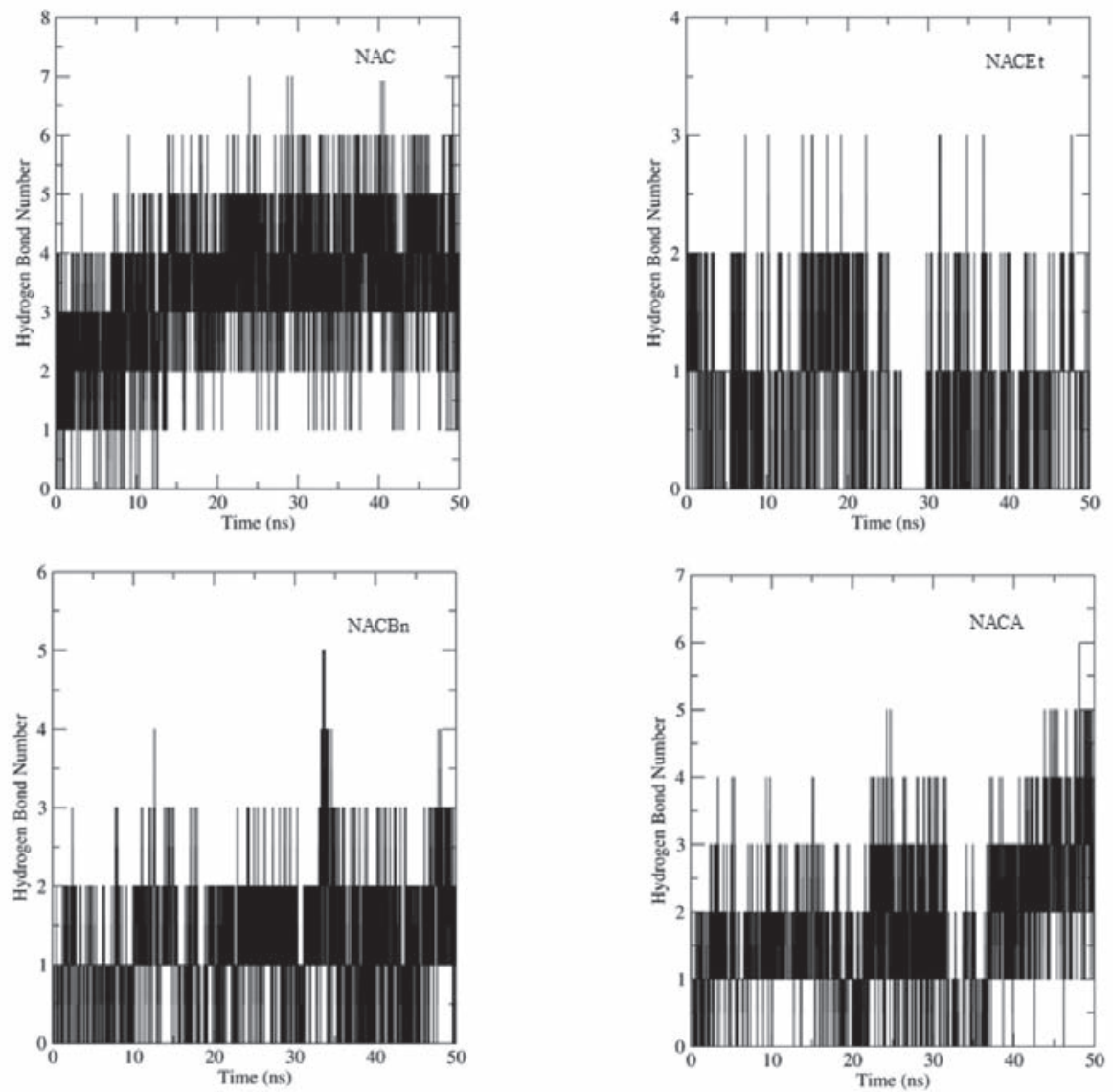

Fig. 4. Number of Hydrogen bond of NAC, NACEt, NACBn and NACA compounds with $M^{\text {pro }}$ plotted along the 50 ns MD simulation 


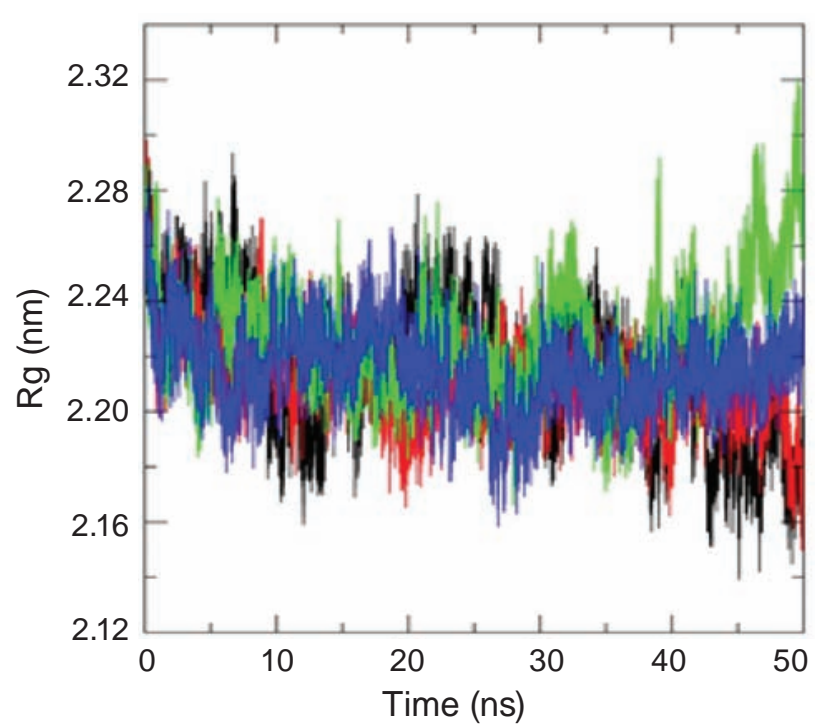

Fig. 5. The radius of gyration $(\mathrm{Rg})$ of $M^{\text {pro }}$ protein with NAC, NACEt, NACBn and NACA complex during 50 ns of MDs. The black line represent NAC, red line represent NACEt, green line represent NACBn and blew line represent NACA

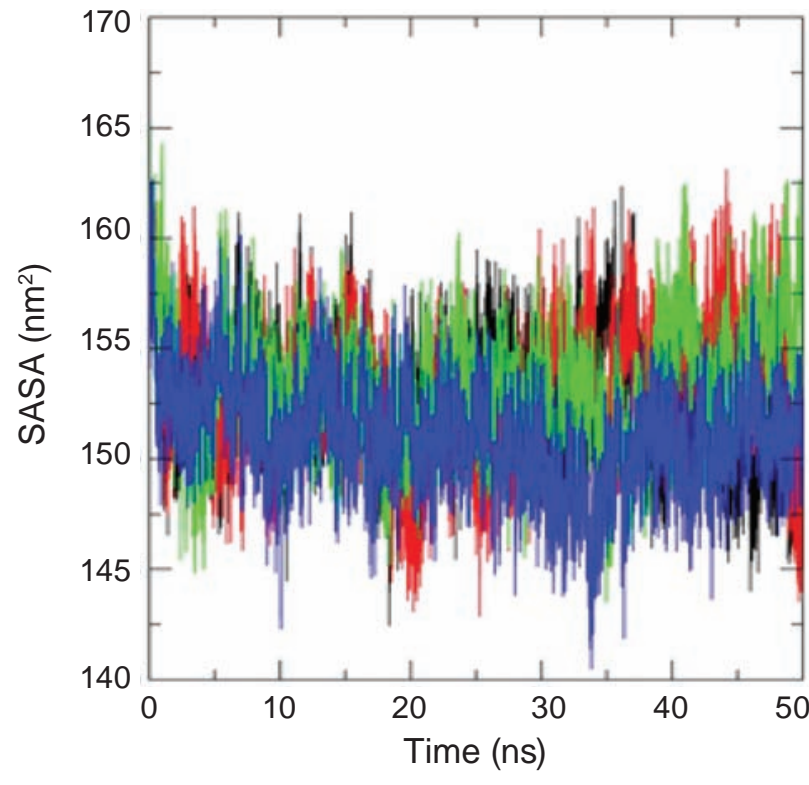

Fig. 6. The total solvent-accessible surface area (SASA) of the $M^{\text {pro }}$ protein with NAC, NACEt, NACBn and NACA complex during 50 ns of MDs. The black line represent NAC, red line represent NACEt, green line represent NACBn and blew line represent NACA

SASA plot indicates greater value of SASA with time that indicate to the binding with NACBn ligand contributed to the structural stability of the $\mathrm{M}^{\text {pro }}$ protein. The comparing the MSD values for NAC, NACEt, NACBn and NACA bound to $\mathrm{M}^{\text {pro }}$ show that

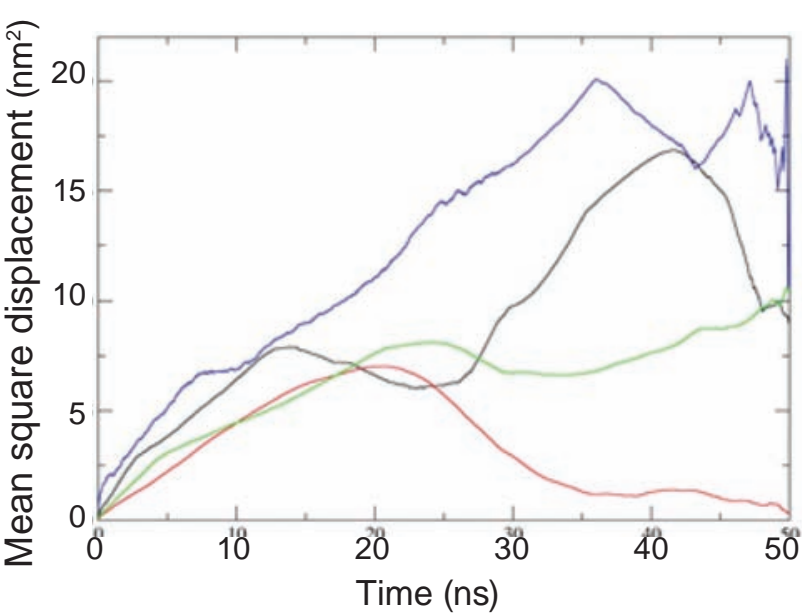

Fig. 7. Time dependence of mean square displacement (MSD) for NAC, NACEt, NACBn and NACA in complex with $M^{\text {pro }}$ protein during 50 ns molecular dynamics (MD) simulation. The black line represent $N A C$, red line represent NACEt, green line represent NACBn and blew line represent NACA

it appears that evidently NACBn, during their simulations, could have interacted with many atoms of protein residues, and consequently increased their difusibility (Fig. 7).

Conclusion. A complex of the best binding configuration of NACBn with protein $\mathrm{M}^{\text {pro }}$ was run MDs in 50 ns. Combining the molecular docking and MDs, the results showed that NACBn ligand might have the ability to inhibit SARS-CoV-2 replication pathway compared to NAC drug. The Topological Polar Surface Area (TPSA) was calculated for all compounds that haves High PSA value (PSA $<75 \AA^{2}$ ) were associated with poor membrane permeability. In the other hand all compounds exhibit computational TPSA values less then $\left(140 \AA^{2}\right)$ haves good intestinal absorption. However, the derivatives do not have adequate blood-brain barrier penetration, as the TPSA values are more than $\left(60 \AA^{2}\right)$. According to values of Lipinski's rule of five: all compounds that have $\log P$ value less than 5 and its molecular masses less than 500 Daltons are in good agreement with the given criteria and can be said to possess good oral bioavailability.

Conflict of interest. Authors have completed the Unified Conflicts of Interest form at http://ukrbiochemjournal.org/wp-content/uploads/2018/12/ coi_disclosure.pdf and declare no conflict of interest.

Funding. This reserch has been supported by University of Babylon, College of Science for Women. 


\section{ВИЗНАЧЕННЯ ЗДАТНОСТІ ЗВ'ЯЗУВАННЯ \\ N-АЦЕТИЛЦИСТЕЇНУ ТА ЙОГО \\ ПОХІДНИХ ІЗ ОСНОВНОЮ \\ ПРОТЕАЗОЮ SARS COV-2 \\ З ВИКОРИСТАННЯМ \\ МОЛЕКУЛЯРНОГО ДОКІНГУ I \\ МОЛЕКУЛЯРНОЇ ДИНАМІКИ}

\section{A. H. Shntaif ${ }^{凶}$, N. A. Alrazzak, A. Bader, A. M. Almarzoqi}

\author{
University of Babylon, College of \\ Science for Women, Iraq; \\ e-mail: ahmed1979sh@gmail.com
}

$\mathrm{N}$-ацетил цистеїн (NAC) використовують у клінічній практиці як антиоксидант і протизапальний засіб, а нещодавно і у лікуванні пацієнтів із COVID-19. За допомогою методів молекулярного докінгу та молекулярної динаміки порівняно взаємодію $\mathrm{N}$-ацетилцистеїну і його похідних 3 основною протеазою SARSCOV-2 (M $\left.{ }^{\text {pro}}\right)$, яка $\epsilon$ необхідною для реплікації та транскрипції вірусу. Показано, що такі похідні $\mathrm{N}$-ацетилцистеїну як бензиловий ефір NAC (NACBn), етиловий ефір NAC (NACEt) та амід NAC (NACA) можуть зв'язуватися із протеазою SARS-COV-2 краще, ніж препарат NAC.

К л ю ч о в і с ло в а: $\mathrm{N}$-ацетилцистеїн, похідні $\mathrm{N}$-ацетилцистеїну, основна протеаза, SARS-COV-2, молекулярний докінг, COVID-19.

\section{References}

1. Zhou P, Yang XL, Wang XG, Hu B, Zhang L, Zhang W, Si HR, Zhu Y, Li B, Huang CL, Chen HD, Chen J, Luo Y, Guo H, Jiang RD, Liu MQ, Chen Y, Shen XR, Wang X, Zheng XS, Zhao K, Chen QJ, Deng F, Liu LL, Yan B, Zhan FX, Wang YY, Xiao GF, Shi ZL. A pneumonia outbreak associated with a new coronavirus of probable bat origin. Nature. 2020; 579(7798): 270-273.

2. Gorbalenya AE, Baker SC, Baric RS, de Groot RJ, Drosten C, Gulyaeva AA, Haagmans BL, Lauber C, Leontovich AM, Neuman BW, Penzar D, Perlman S, Poon LLM, Samborskiy DV, Sidorov IA, Sola I, Ziebuhr J. The species Severe acute respiratory syndromerelated coronavirus: classifying 2019-nCoV and naming it SARS-CoV-2. Nat Microbiol. 2020; 5(4): 536-544.
3. Hui DS, Azhar EI , Madani TA, Ntoumi F, Kock R, Dar O, Ippolito G, Mchugh TD, Memish ZA, Drosten C, Zumla A, Petersen E. The continuing 2019-nCoV epidemic threat of novel coronaviruses to global health - The latest 2019 novel coronavirus outbreak in Wuhan, China. Int J Infect Dis. 2020; 91: 264-266.

4. Ren LL, Wang YM, Wu ZQ, Xiang ZC, Guo L, Xu T, Jiang YZ, Xiong Y, Li YJ, Li XW, Li H, Fan GH, Gu XY, Xiao Y, Gao H, Xu JY, Yang F, Wang XM, Wu C, Chen L, Liu YW, Liu B, Yang J, Wang XR, Dong J, Li L, Huang CL, Zhao JP, Hu Y, Cheng ZS, Liu LL, Qian ZH, Qin C, Jin Q, Cao B, Wang JW. Identification of a novel coronavirus causing severe pneumonia in human: a descriptive study. Chin Med $J$ (Engl). 2020; 133(9): 1015-1024.

5. Cui J, Li F, Shi ZL. Origin and evolution of pathogenic coronaviruses. Nat Rev Microbiol. 2019; 17(3): 181-192.

6. Chou CC, Shen CF, Chen SJ, Chen HM, Wang YC, Chang WS, Chang YT, Chen WY, Huang CY, Kuo CC, Li MC, Lin JF, Lin SP, Ting SW, Weng TC, Wu PS, Wu UI, Lin PC, Lee SSJ, Chen YS, Liu YC, Chuang YC, Yu CJ, Huang LM, Lin MC. Recommendations and guidelines for the treatment of pneumonia in Taiwan. J Microbiol Immunol Infect. 2019; 52(1): 172-199.

7. Su IC, Lee KL, Liu HY, Chuang HC, Chen LY, Lee YJ. Severe community-acquired pneumonia due to Pseudomonas aeruginosa coinfection in an influenza $\mathrm{A}(\mathrm{H} 1 \mathrm{N1}) \mathrm{pdm} 09$ patient. $J$ Microbiol Immunol Infect. 2019; 52(2): 365-366.

8. Hung HM, Yang SL, Chen CJ, Chiu CH, Kuo CY, Huang KYA, Lin TY, Hsieh YC, Gong YN, Tsao KC, Huang YC. Molecular epidemiology and clinical features of rhinovirus infections among hospitalized patients in a medical center in Taiwan. J Microbiol Immunol Infect. 2019; 52(2): 233-241.

9. Lin GL, Lu CY, Chen JM, Lee PI, Ho SY, Weng KC, Huang LM, Chang LY. Molecular epidemiology and clinical features of adenovirus infection in Taiwanese children, 2014. J Microbiol Immunol Infect. 2019; 52(2): 215-224.

10. Lu R, Zhao $X$, Li J, Niu P, Yang B, Wu H, Wang W, Song H, Huang B, Zhu N, Bi Y, Ma X, Zhan F, Wang L, Hu T, Zhou H, Hu Z, Zhou W, Zhao L, Chen J, Meng Y, Wang J, Lin Y, Yuan J, Xie Z, Ma J, Liu WJ, Wang D, Xu W, Holmes EC, 
Gao GF, Wu G, Chen W, Shi W, Tan W. Genomic characterisation and epidemiology of 2019 novel coronavirus: implications for virus origins and receptor binding. Lancet. 2020; 395(10224): 565574.

11. Zhu N, Zhang D, Wang W, Li X, Yang B, Song J, Zhao X, Huang B, Shi W, Lu R, Niu P, Zhan F, Ma X, Wang D, Xu W, Wu G, Gao GF, Tan W. A Novel Coronavirus from Patients with Pneumonia in China, 2019. N Engl J Med. 2020; 382(8): 727-733.

12. Simmonds P, Adams MJ, Benkő M, Breitbart M, Brister JR, Carstens EB, Davison AJ, Delwart E, Gorbalenya AE, Harrach B, Hull R, King AMQ, Koonin EV, Krupovic M, Kuhn JH, Lefkowitz EJ, Nibert ML, Orton R, Roossinck MJ, Sabanadzovic S, Sullivan MB, Suttle CA, Tesh RB, van der Vlugt RA, Varsani A, Zerbini FM. Consensus statement: Virus taxonomy in the age of metagenomics. Nat Rev Microbiol. 2017; 15(3): 161-168.

13. Chen L, Liu W, Zhang Q, Xu K, Ye G, Wu W, Sun Z, Liu F, Wu K, Zhong B, Mei Y, Zhang W, Chen Y, Li Y, Shi M, Lan K, Liu Y. RNA based mNGS approach identifies a novel human coronavirus from two individual pneumonia cases in 2019 Wuhan outbreak. Emerg Microbes Infect. 2020; 9(1): 313-319.

14. Jiang S, Du L, Shi Z. An emerging coronavirus causing pneumonia outbreak in Wuhan, China: calling for developing therapeutic and prophylactic strategies. Emerg Microbes Infect. 2020; 9(1): 275-277.

15. Li X, Song Y, Wong G, Cui J. Bat origin of a new human coronavirus: there and back again. Sci China Life Sci. 2020; 63(3): 461-462.

16. Zhang L, Lin D, Sun X, Curth U, Drosten C, Sauerhering L, Becker S, Rox K, Hilgenfeld R. Crystal structure of SARS-CoV-2 main protease provides a basis for design of improved $\alpha$-ketoamide inhibitors. Science. 2020; 368(6489): 409-412.

17. Jin Z, Du X, Xu Y, Deng Y, Liu M, Zhao Y, Zhang B, Li X, Zhang L, Peng C, Duan Y, Yu J, Wang L, Yang K, Liu F, Jiang R, Yang X, You T, Liu X, Yang X, Bai F, Liu H, Liu X, Guddat LW, Xu W, Xiao G, Qin C, Shi Z, Jiang H, Rao Z, Yang H. Structure of M pro from SARS-CoV-2 and discovery of its inhibitors. Nature. 2020; 582(7811): 289-293.
18. Vranová E, Inzé D, Van Breusegem F. Signal transduction during oxidative stress. J Exp Bot. 2002; 53(372): 1227-1236.

19. Turpaev KT. Reactive oxygen species and regulation of gene expression. Biochemistry (Mosc). 2002; 67(3): 281-292.

20. Sanguinetti CM. N-acetylcysteine in COPD: why, how, and when? Multidiscip Respir Med. 2016; 11: 8.

21. Gunnell D, Murray V, Hawton K. Use of paracetamol (acetaminophen) for suicide and nonfatal poisoning: worldwide patterns of use and misuse. Suicide Life Threat Behav. 2000; 30(4): 313-326.

22. Cairney DG, Beckwith HKS, Al-Hourani K, Eddleston M, Bateman DN, Dear JW. Plasma paracetamol concentration at hospital presentation has a dose-dependent relationship with liver injury despite prompt treatment with intravenous acetylcysteine. Clin Toxicol (Phila). 2016; 54(5): 405-410.

23. Samuni Y, Goldstei S, Dean OM, Berk M. The chemistry and biological activities of N-acetylcysteine. Biochim Biophys Acta. 2013; 1830(8): 4117-4129.

24. Omara FO, Blakley BR, Bernier J, Fournier M. Immunomodulatory and protective effects of $\mathrm{N}$-acetylcysteine in mitogen-activated murine splenocytes in vitro. Toxicology. 1997; 116(1-3): 219-226.

25. Shi Z, Puyo CA. N-Acetylcysteine to Combat COVID-19: An Evidence Review. Ther Clin Risk Manag. 2020; 16: 1047-1055.

26. Guthappa R. Molecular Docking Studies of N-Acetyl Cysteine, Zinc Acetyl Cysteine and Niclosamide on SARS Cov 2 Protease and Its Comparison with Hydroxychloroquine. ChemRxiv. Cambridge: Cambridge Open Engage; 2020. Preprint.

27. Thimmasandra Narayan R. Binding Ability Studies of Arginine, Citrulline, N-Acetyl Citrulline and Thiocitrulline with SARS Cov2 Main Protease Using Molecular Docking Studies. ChemRxiv. Cambridge: Cambridge Open Engage; 2020. Preprint.

28. Badavath VN, Kumar A, Samanta PK, Maji S, Das A, Blum G, Jha A, Sen A. Determination of potential inhibitors based on isatin derivatives against SARS-CoV-2 main protease (m pro): a molecular docking, molecular dynamics and 
structure-activity relationship studies. J Biomol Struct Dyn. 2020; 1-19.

29. Xue X, H Yu, Yang H, Xue F, Wu Z, Shen W, Li J, Zhou Z, Ding Y, Zhao Q, Zhang XC,
Liao M, Bartlam M, Rao Z. Structures of two coronavirus main proteases: implications for substrate binding and antiviral drug design. $J$ Virol. 2008; 82(5): 2515-2527. 